University of Nebraska - Lincoln

DigitalCommons@University of Nebraska - Lincoln

1981

\title{
Genetic Structure of Two Species of Waterstriders (Gerridae: Hemiptera) with Differing Degrees of Winglessness
}

Anthony J. Zera

University of Nebraska - Lincoln, azera1@unl.edu

Part of the Microbiology Commons

Zera, Anthony J., "Genetic Structure of Two Species of Waterstriders (Gerridae: Hemiptera) with Differing Degrees of Winglessness" (1981). Anthony Zera Publications. 33.

https://digitalcommons.unl.edu/bioscizera/33

This Article is brought to you for free and open access by the Papers in the Biological Sciences at DigitalCommons@University of Nebraska - Lincoln. It has been accepted for inclusion in Anthony Zera Publications by an authorized administrator of DigitalCommons@University of Nebraska - Lincoln. 


\title{
Genetic Structure of Two Species of Waterstriders (Gerridae: Hemiptera) with Differing Degrees of Winglessness
}

\begin{abstract}
Anthony J. Zera
Biological Science Group, University of Connecticut, Storrs, Connecticut 06268 (Present address: Department of Ecology and Evolution, State University of New York at Stony Brook, Stony Brook, New York 11794)

Submitted November 1979; revised July 1980. This paper is part of a dissertation submitted to the Graduate School of the University of Connecticut in partial fulfillment of the requirements for the M.S. degree.
\end{abstract}

The Gerridae (Hemiptera: Insecta) is a worldwide family whose constituent species exhibit dramatic inter- and intra-specific variation in the degree of winglessness (Brinkhurst, 1960; Vepsäläinen, 1978; Calabrese, 1979). At one extreme, the family contains species which are fully winged in all populations and during all seasons, while several species consist almost exclusively of wingless morphs over large geographical ranges and during all seasons. Many species exhibit the intermediate case of wingpolymorphism: the occurrence of various combinations of fully winged, partially winged and/ or wingless morphs in the same population at the same time. Various wing-polymorphic species show differing patterns of spatial and/or temporal changes in morph ratios and patterns may vary both inter- and intraspecifically.

The dramatic differences in frequency of winged morphs pose intriguing questions regarding the evolutionary forces responsible for degree of winglessness and the relationship between degree of winglessness and genetic structure of water-strider species. One might expect genetic structure to be strongly influenced by degree of winglessness via reduction of flight dispersal ability and consequent reduced gene flow. Thus, species composed almost exclusively of wingless individuals should exhibit patterns of marked genetic differentiation and reduced levels of within-population variability typically found in organisms with reduced dispersal (Avise and Selander, 1972; Laing et al.,
1976; Selander, 1976). However, additional factors may counteract the effects of reduced dispersal by flight. Gene flow among populations may occur via alternate modes of dispersal, including passive stream drift and overland dispersal (Riley, 1920). Furthermore, marked genetic differentiation among populations is not a necessary consequence of severely reduced dispersal if locality-independent balancing selection is operating (McKechnie et al., 1975).

In this study I compare patterns of spatial variation of polymorphic enzyme-loci and levels of variability in two species of waterstriders (Gerridae: Hemiptera) with differing degrees of winglessness: the nearly wingless Gerris remigis and the wing-polymorphic Limnoporus canaliculatus.

\section{Species Studied}

Gerris remigis is the most widely distributed and the most abundant North American gerrid species (Drake and Harris, 1934), occurring throughout the continental United States, Mexico, south to Guatemala. In the eastern U.S., G. remigis occurs principally on flowing water. $\mathrm{Ca}$ labrese (1979) recorded greater than $99 \%$ wingless morphs in museum and field collections of G. remigis in Connecticut. Limnoporus canaliculatus, which until recently was known as Gerris canaliculatus (Anderson, 1975), ranges from Florida to Maine and west to Illinois and Michigan (Calabrese, 1974). The species occurs on ponds, swamps and sluggish streams. 
TABLE 1. Location of sampling sites for Gerris remigis and Limnoporus canaliculatus and the frequency of wingless morphs found at each site.

\begin{tabular}{|c|c|c|}
\hline \multirow[b]{2}{*}{ Sampling site } & \multicolumn{2}{|c|}{ Frequency of wingless morphs* } \\
\hline & G. remigis & L. canaliculatus \\
\hline Beddington, Maine (BD) & $1.00(44)^{* *}$ & $0.03(30)$ \\
\hline Hartland, Vermont (HT) & $1.00(47)$ & - \\
\hline Petersham, Mass. (PT) & $1.00(50)$ & $0.29(49)$ \\
\hline Swift River, Mass. (SW) & $1.00(56)$ & - \\
\hline Schoolhouse Brook, Conn. (SB) & $1.00(59)$ & - \\
\hline Pink Ravine, Conn. (PR) & $1.00(41)$ & $0.15(39)$ \\
\hline Willimantic, Conn. (WI) & - & $0.79(42)$ \\
\hline Niantic, Conn. (NI) & $1.00(59)$ & $0.54(45)$ \\
\hline Maplewood, N.J. (MW) & $0.94(107)$ & - \\
\hline Bass River State Park, N.J. (BR) & - & $0.96(46)$ \\
\hline Shenandoah Nat. Park, Va. (SH) & $1.00(24)$ & - \\
\hline Athens, Georgia (AT) & - & $0.72(40)$ \\
\hline
\end{tabular}

* Frequency of wingless morphs was recorded in Sept., 1976, for all populations of L. canaliculatus, except for the Beddington population which was sampled in August, 1976. Frequency of wingless morphs was recorded at various times from July to October, 1976-1977, for populations of G. remigis (see Materials and Methods).

$* *$ Numbers in parentheses are the total number of individuals scored for morph type.

Populations of L. canaliculatus consist of various proportions of fully-winged, wingless, and (very rarely) short-winged individuals. The frequency of fully-winged individuals varies seasonally, the highest frequency occurring from September to November in Connecticut and Virginia populations (Bobb, 1951; Calabrese, 1979). Calabrese (1979) reported that Connecticut populations contained greater than $25 \%$ winged individuals during all seasons. However, I have found Connecticut and Massachusetts populations to consist almost exclusively of wingless individuals from July through early August (Zera, unpubl.). This observation is similar to the data of Bobb (1951) for Virginia populations.

Both $G$. remigis and $L$. canaliculatus are at least bivoltine in Connecticut (Zera and Saks, unpubl.), while in Florida, L. canaliculatus breeds throughout the year (Penn and Goldsmith, 1950). In Connecticut, both species overwinter as adults. Individuals emerge the following April-May and mate throughout this time. Adults of the subsequent summer generation begin to emerge in late June, and adults of both species can be seen continuously from this time through late October. Mating pairs are commonly seen from July through August.
There are no published data for dispersal in either species. However, it is likely that population mixing occurs in L. canaliculatus as a result of dispersal of winged individuals to and from overwintering sites, as has been reported for several European gerrid species (see Discussion).

\section{Sampling and Electrophoresis}

Samples were taken from eight populations of Gerris remigis ranging from Maine to Virginia and seven populations of Limnoporus canaliculatus ranging from Maine to Georgia during July-October of 1976 (Table 1). No sampling sites were directly connected by water. All sites contained water throughout the year.

The number of winged and wingless morphs was recorded in each fall (Sept.) population sample of $L$. canaliculatus. The frequency of morphs was recorded in each population of $G$. remigis in both summer and fall since there is no evidence for seasonal change in the near unitary frequency of wingless morphs (Calabrese, 1979).

The following enzymes were studied in the two species: $\alpha$-Glycerophosphate dehydrogenase ( $\alpha$-Gpdh, E.C. 1.1.1.8); Malate dehydro- 
genase (Mdh, E.C. 1.1.1.37), anodal Mdh-1 and cathodal Mdh-2; Isocitrate dehydrogenase (Idh-1, E.C. 1.1.1.42); Malic enzyme (Me, E.C. 1.1.1.40); and Esterase (Est, E.C. 3.1.1.1), Est3 and Est-4.

In order to obtain a larger sample of loci for heterozygosity estimates, three populations of L. canaliculatus (Petersham, Pink Ravine and Niantic) and two populations of G. remigis (Pink Ravine and Niantic) were resampled in 1977 for variation in the following additional enzymes: Glutamate-oxaloacetate transaminase (GOT, E.C. 2.6.1. 1), GOT-1 and GOT- 2; 6Phosphogluconate dehydrogenase (6- PGDH, E. C. 1.1.1.43); Phosphoglucose isomerase (PGI, E. C. 5.3.1.9); Glucose-6- phosphate dehydrogenase (G-6-PDH, E.C. 1.1.1.49); Leucine napthylamidase (NAP, E.C. 3.4.-.- ); Acid phosphatase (ACPH, E.C. 3.1.3.2); Fumarase (FUM, E.C. 4.2. 1.2); Xanthine dehydrogenase (XDH, E.C. 1.2.3.2); Phosphoglucomutase (PGM, E.C. 2.7.5.1); Peptidase (PEP, E.C. 3.4.1.-); and an additional Isocitrate dehydrogenase locus (IDH-2, E.C. 1.1.1.42). In total, 18 loci were examined in G. remigis and 16 loci in L. canaliculatus.

In addition to the populations listed above, a new population (Swift) of G. remigis was sampled during 1977 for variation at the 18 loci surveyed in the other populations of this species.

Gerrids were homogenized in $0.1 \mathrm{ml}(G$. remigis) or $0.05 \mathrm{ml}$ (L. canaliculatus) of 0.05 $\mathrm{M}$ Tris-HCl buffer, $\mathrm{pH} 7.0$, containing $0.01 \mathrm{M}$ mercaptoethanol. Crude homogenates were absorbed onto paper wicks and applied to horizontal starch gels prepared with Electrostarch (lots 307 or 371; Otto Hiller, Madison, Wisconsin) at a concentration of $12 \%(\mathrm{w} / \mathrm{v})$.

The $0.135 \mathrm{M}$ Tris-citrate buffer of Shaw and Prasad (1970) was adjusted to different pH's by varying the concentration of citric acid. $\mathrm{MDH}$, ME, IDH, GOT, $a$-GPDH, FUM, ACPH in $L$. canaliculatus only, and PGI were resolved at $\mathrm{pH}$ 7.3. G-6-PDH and 6-PGDH were resolved at $\mathrm{pH} 8.0$ and $\mathrm{ACPH}$ in G. remigis was resolved at $\mathrm{pH}$ 6.8. Phosphoglucomutase was resolved using the Tris-maleate-EDTA buffer of Shaw and Prasad (1970) and XDH was resolved us- ing buffer "B" of Ayala (1972). Peptidase, NAP, and Esterases were resolved using the $\mathrm{LiOH}$ buffer of Selander et al. (1971).

Gels were stained for the appropriate enzymes as in Shaw and Prasad (1970). For $\mathrm{ACPH}$, gels were soaked in $0.25 \mathrm{M}$ Na-acetate buffer, $\mathrm{pH} 4.5$, for $30 \mathrm{~min}$ prior to staining.

Observed genotypic numbers were compared with their Hardy-Weinberg expectations by the $\chi^{2}$-test (Sokal and Rohlf, 1969). Geographic variation of polymorphic loci was analyzed using $\mathrm{R} \times \mathrm{C}$ tests of homogeneity of genotypic numbers (Workman and Niswander, 1970). Polymorphic loci surveyed during 1976 as well as additional polymorphic loci discovered during the 1977 sampling were analyzed. Rare genotypic classes were pooled with their most electrophoretically similar class until not more than $20 \%$ of the cells of the $\mathrm{R} \times \mathrm{C}$ table contained expected values less than five and no cell contained an expected value less than one (Conover, 1971). These criteria could not be met for the weakly polymorphic $I d h-1$ and Me loci of L. canaliculatus. $\mathrm{R} \times \mathrm{C}$ tests of homogeneity were still performed on these loci, since they conform to less stringent criteria (i.e., no cell of an $\mathrm{R} \times \mathrm{C}$ table with an expected value less than one, Lewontin and Felsenstein, 1965). A posteriori STP tests (Sokal and Rohlf, 1969) were; done on all $\mathrm{R} \times \mathrm{C}$ tests of homogeneity. The $M d h-2$ and Est-4 loci of $G$. remigis were not analyzed statistically for geographical variation, since it is obvious by inspection that marked geographical variation is present.

Two values of average heterozygosity per individual $(\mathrm{H})$ were calculated. One value, $H_{t}$, was calculated using all loci surveyed in each species, while a second value, $H_{h}$, was calculated using only the 15 presumed homologous loci surveyed in both species. The calculation of average heterozygosity using only homologous loci was done since this eliminates the confounding effects of interlocus variation in interspecific comparisons of average heterozygosity (Selander, 1976). For this reason, only $H_{h}$, was used in the comparison of heterozygosity between the two species. 
TABLE 2. Allele frequencies for polymorphic loci surveyed in populations of Gerris remigis ( $\mathrm{n}=$ number of individuals surveyed; alleles with frequencies less than 0.05 in all populations are not shown).

\begin{tabular}{|c|c|c|c|c|c|c|c|c|c|c|}
\hline \multirow[b]{2}{*}{ Enzyme } & \multirow{2}{*}{$\begin{array}{l}\text { Allele and } \\
\text { sample size }\end{array}$} & \multicolumn{9}{|c|}{ Locality } \\
\hline & & $\mathrm{BD}$ & $\mathrm{HT}$ & PT & Sw & SB & PR & NI & MW & SH \\
\hline \multirow[t]{4}{*}{ MDH-1 } & $n$ & 44 & 46 & 70 & 44 & 48 & 67 & 70 & 60 & 24 \\
\hline & $a$ & 0.000 & 0.000 & 0.000 & 0.000 & 0.000 & 0.000 & 0.000 & 0.000 & 0.979 \\
\hline & $b$ & 1.000 & 0.945 & 0.850 & 0.943 & 0.990 & 0.992 & 0.939 & 1.000 & 0.021 \\
\hline & $c$ & 0.000 & 0.055 & 0.150 & 0.057 & 0.010 & 0.008 & 0.061 & 0.000 & 0.000 \\
\hline \multirow[t]{4}{*}{ MDH-2 } & $n$ & 40 & 47 & 67 & 41 & 97 & 112 & 88 & 50 & 19 \\
\hline & $a$ & 0.000 & 0.000 & 0.000 & 0.231 & 0.887 & 0.969 & 0.989 & 1.000 & 0.000 \\
\hline & $b$ & 0.057 & 0.000 & 0.000 & 0.000 & 0.000 & 0.000 & 0.000 & 0.000 & 0.000 \\
\hline & $c$ & 0.943 & 1.000 & 1.000 & 0.769 & 0.113 & 0.031 & 0.011 & 0.000 & 1.000 \\
\hline \multirow[t]{3}{*}{ IDH-1 } & $n$ & 41 & 39 & 76 & 44 & 23 & 44 & 58 & 44 & 6 \\
\hline & $a$ & 0.929 & 1.000 & 1.000 & 1.000 & 1.000 & 1.000 & 1.000 & 1.000 & 1.000 \\
\hline & $b$ & 0.071 & 0.000 & 0.000 & 0.000 & 0.000 & 0.000 & 0.000 & 0.000 & 0.000 \\
\hline \multirow[t]{5}{*}{ EST-3 } & $n$ & - & - & - & 52 & 55 & 56 & 54 & - & - \\
\hline & $a$ & - & - & - & 0.000 & 0.000 & 0.000 & 0.075 & - & - \\
\hline & $b$ & - & - & - & 0.192 & 0.109 & 0.170 & 0.270 & - & - \\
\hline & $c$ & - & - & - & 0.808 & 0.891 & 0.830 & 0.575 & - & - \\
\hline & $d$ & - & - & - & 0.000 & 0.000 & 0.000 & 0.085 & - & - \\
\hline \multirow[t]{4}{*}{ EST -4} & $n$ & - & - & - & - & - & - & - & 29 & 21 \\
\hline & $a$ & - & - & - & - & - & - & - & 0.000 & 0.977 \\
\hline & $b$ & - & - & - & - & - & - & - & 0.206 & 0.023 \\
\hline & $c$ & - & - & - & - & - & - & - & $0: 794$ & 0.000 \\
\hline \multirow[t]{4}{*}{$\mathrm{ACPH}$} & $n$ & - & - & - & 16 & 43 & 52 & - & - & - \\
\hline & $a$ & - & - & - & 0.000 & 0.094 & 0.115 & - & - & - \\
\hline & $b$ & - & - & - & 0.906 & 0.872 & 0.866 & - & - & - \\
\hline & $c$ & - & - & - & 0.094 & 0.034 & 0.019 & - & - & - \\
\hline \multirow[t]{3}{*}{ PGM } & $n$ & - & - & - & 52 & 41 & 52 & - & - & - \\
\hline & $a$ & - & - & - & 0.885 & 0.988 & 0.981 & - & - & - \\
\hline & $b$ & - & - & - & 0.115 & 0.012 & 0.019 & - & - & - \\
\hline
\end{tabular}

\section{RESULTS}

Eleven of 18 loci surveyed in G. remigis were monomorphic (a-Gpdh, Me, Got-1, Got-2, 6 Pgdh, Fum, Pgi, G-6-pdh, Nap, Pep, and Xdh), while 8 of 16 loci in L. canaliculatus were monomorphic (Got-1, Got-2, Fum, Nap, G-6$p d h, M d h-1, I d h-2$, and $X d h)$. A monomorphic locus is defined as a locus containing one and the same allele with a frequency greater than 0.95 in all sampled populations.

Allele frequencies of polymorphic loci are given in Tables 2 and 3. No significant deviations from Hardy-Weinberg expectations were observed, except at the 6-Pgdh locus in the Niantic population of L. canaliculatus. No biological significance is attributed to this single deviation.
Frequency of Wingless Morphs

All sampled G. remigis were wingless, except for six individuals from the Maplewood population (Table 1). In contrast, the frequency of wingless individuals varied considerably among populations of $L$. canaliculatus in the Beddington and Bass River populations, respectively (Table 1).

\section{Geographical Variation}

Five of six polymorphic loci in G. remigis exhibited significant among-population heterogeneity $\left(M d h-1, G_{(8)}=243.72, P<.005 ; M d h-\right.$ 2 , heterogeneous by inspection; Est-3, $G_{(3)}=$ $14.35, P<.005$; Est-4, heterogeneous by inspection; Pgm, $\left.G_{(2)}=13.81, P<.005\right)$. Acid 
TABLE 3. Allele frequencies for polymorphic loci surveyed in populations of Limnoporus canaliculatus $(\mathrm{n}=$ number of individuals surveyed; alleles with frequencies less than 0.05 in all populations are not shown).

\begin{tabular}{|c|c|c|c|c|c|c|c|c|}
\hline \multirow[b]{2}{*}{ Enzyme } & \multirow{2}{*}{$\begin{array}{l}\text { Allele and } \\
\text { sample size }\end{array}$} & \multicolumn{7}{|c|}{ Locality } \\
\hline & & BD & PT & PR & WI & $\mathrm{NI}$ & BR & AT \\
\hline \multirow{4}{*}{$\alpha-\mathrm{GPDH}$} & $n$ & 29 & 101 & 97 & 44 & 66 & 44 & 45 \\
\hline & $a$ & 0.068 & 0.045 & 0.021 & 0.092 & 0.062 & 0.000 & 0.000 \\
\hline & $b$ & 0.743 & 0.782 & 0.820 & 0.805 & 0.744 & 0.771 & 0.767 \\
\hline & $c$ & 0.189 & 0.173 & 0.159 & 0.103 & 0.194 & 0.229 & 0.233 \\
\hline \multirow[t]{6}{*}{ EST-3 } & $n$ & - & 57 & 48 & 41 & 45 & 42 & 39 \\
\hline & $a$ & - & 0.027 & 0.052 & 0.037 & 0.122 & 0.047 & 0.025 \\
\hline & $b$ & - & 0.561 & 0.407 & 0.549 & 0.457 & 0.120 & 0.334 \\
\hline & $c$ & - & 0.263 & 0.468 & 0.317 & 0.355 & 0.130 & 0.602 \\
\hline & $d$ & - & 0.149 & 0.073 & 0.073 & 0.055 & 0.607 & 0.039 \\
\hline & $e$ & - & 0.000 & 0.000 & 0.024 & 0.011 & 0.096 & 0.000 \\
\hline \multirow[t]{3}{*}{ IDH-1 } & $n$ & 30 & 49 & 72 & 55 & 64 & 35 & 62 \\
\hline & $a$ & 0.000 & 0.000 & 0.048 & 0.000 & 0.015 & 0.086 & 0.032 \\
\hline & $b$ & 1.000 & 1.000 & 0.952 & 1.000 & 0.985 & 0.914 & 0.968 \\
\hline \multirow[t]{3}{*}{ ME } & $n$ & 27 & 52 & 40 & 36 & 50 & 35 & 24 \\
\hline & $a$ & 0.000 & 0.038 & 0.000 & 0.042 & 0.010 & 0.271 & 0.000 \\
\hline & $b$ & 1.000 & 0.962 & 1.000 & 0.958 & 0.990 & 0.729 & 1.000 \\
\hline \multirow[t]{3}{*}{ PGM } & $n$ & - & 51 & 52 & - & 48 & - & - \\
\hline & $a$ & - & 0.271 & 0.295 & - & 0.317 & - & - \\
\hline & $b$ & - & 0.729 & 0.705 & - & 0.683 & - & - \\
\hline \multirow[t]{3}{*}{ PGI } & $n$ & - & 45 & 72 & - & 32 & - & - \\
\hline & $a$ & - & 0.366 & 0.417 & - & 0.579 & - & - \\
\hline & $b$ & - & 0.634 & 0.583 & - & 0.421 & - & - \\
\hline \multirow[t]{6}{*}{$\mathrm{ACPH}$} & $n$ & - & 33 & 42 & - & 30 & - & - \\
\hline & $a$ & - & 0.000 & 0.072 & - & 0.000 & - & - \\
\hline & $b$ & - & 0.318 & 0.297 & - & 0.283 & - & - \\
\hline & $c$ & - & 0.213 & 0.072 & - & 0.166 & - & - \\
\hline & $d$ & - & 0.363 & 0.452 & - & 0.467 & - & - \\
\hline & $e$ & - & 0.106 & 0.107 & - & 0.084 & - & - \\
\hline \multirow[t]{5}{*}{ 6-PGDH } & $n$ & - & - & - & - & 32 & - & - \\
\hline & $a$ & - & - & - & - & 0.281 & - & - \\
\hline & $b$ & - & - & - & - & 0.360 & - & - \\
\hline & $c$ & - & - & - & - & 0.124 & - & - \\
\hline & $d$ & - & - & - & - & 0.235 & - & - \\
\hline
\end{tabular}

phosphatase, the only polymorphic locus which did not exhibit significant among-population heterogeneity, approached statistical significance $\left(G_{(2)}=5.88, .1>P>.05\right)$. In contrast, five of seven polymorphic loci surveyed in $L$. canaliculatus exhibited no significant amongpopulation heterogeneity $\left(\alpha-G p d h, G_{(6)}=7.54\right.$, $P>.1, I d h-1, G_{(6)}=10.99, .1>P>.05 ; P g m$, $G_{(4)}=1.57, P>1$. Pgi, $G_{(4)}=7.48, P>.1$; Acph, $G_{(6)}=4.34, P>$.1). Of the two loci which were significantly heterogeneous (Est-3, $G_{(20)}$ $=133.65, P<.005$ and $M e, G_{(6)}=53.93, P<$
.005), significant heterogeneity at the $M e$ locus was due to the Bass River population. The subset of samples excluding the Bass River population was statistically homogeneous. Similarly, the majority (but not all) of the heterogeneity at the Est-3 locus was due to the Bass River population. This population was the only population to form a unique subset in the STP analysis.

The pattern of variation was very different for polymorphic loci of the two species. Four of six polymorphic loci of G. remigis (Mdh-1, Mdh-2, Est-3, Est-4) exhibited sharp disconti- 
nuities in allele frequencies with different alleles fixed in some populations at the $M d h-2$ locus and nearly fixed at the $M d h-1$ locus (Table 2). At the Est-4 locus, an allele which was nearly fixed in the Shenandoah population was absent from the Maplewood population. However, at each locus in L. canaliculatus, the same allele (or pair of alleles at the Est-3 locus) predominated in all populations, with the exception of the Est-3 locus in the Bass River population (Table 3).

Local differentiation among populations of G. remigis was marked. For example, the STP analysis of the Est-3 locus showed significant among-population heterogeneity for the Connecticut samples. Different alleles predominated at the $M d h-2$ locus in the Swift and Pink Ravine populations. These were also significantly different at the Pgm locus. Populations separated by five miles or less were significantly different at the $M d h-2$ locus (Pink Ravine and Schoolhouse Brook, $G_{(1)}=4.77, P$ $<.05$; Swift and Petersham, $G_{(I)}=15.17, P<$ $.005)$. No local differentiation was observed at polymorphic loci in L. canaliculatus. Esterase3 , although exhibiting significant heterogeneity for the total sample of all populations, exhibited no significant among-population heterogeneity for the subset of samples north of Bass River.

\section{Average Heterozygosity}

Since $H_{h}$ and $H_{t}$ (see Materials and Methods) were essentially identical in each species, only $H_{h}$ values will be reported. Average heterozygosity for $G$. remigis $(H=0.058 \pm 0.026)$ was significantly lower than for $L$. canaliculatus $(H=0.234 \pm 0.072)$, as tested by Wilcoxon's signed ranks test $(T S=13, P<, 025$; two tailed test).

\section{Discussion}

Gerris remigis and Limnoporus canaliculatus differ markedly, both in degree of population differentiation at polymorphic loci and in amounts of variability within populations.
L. canaliculatus exhibits the pattern of geographical variation and levels of variability typically found in continental insect species (Ayala, 1972; Lewontin, 1974) and other winged gerrid species (Varvio-Aho et al., 1978; VarvioAho and Pamilo, 1979). In these species (as in L. canaliculatus) allele frequencies of polymorphic loci are often homogeneous over large distances. Average heterozygosity for L. canaliculatus $(0.234 \pm 0.072)$ is within the range for "typical" insects or invertebrates (Powell, 1975; Selander, 1976).

In contrast to $L$. canaliculatus, polymorphic loci of $G$. remigis typically exhibit marked spatial variation of allele frequencies, sometimes over short distances. Average heterozygosity in G. remigis $(\mathrm{H}=0.058 \pm 0.026)$ is well below the value for "typical" insects or invertebrates (Powell, 1975; Selander, 1976). Allozyme data for $G$. remigis are similar to data obtained for species inhabiting geographical or ecological islands (Avise and Selander, 1972; Saura et al., 1973; Laing et al., 1976; Selander, 1976). For example, in six cave populations of troglobite beetle, Ptomaphagus hirtus, amounts of genetic variability were about one-third that of "typical" invertebrates. Of six polymorphic loci studied, different alleles were fixed at three loci, while large spatial differences in allele frequencies were observed at the other three polymorphic loci (Laing et al., 1976).

The similarity of the allozyme data between G. remigis and other "island" species, where reduced gene flow is either known or strongly inferred, suggests that gene flow is similarly reduced among populations of G. remigis. Reduced gene flow would result in a population structure consisting of isolated demes which could differentiate due to selection and/or drift, accounting for both the degree and pattern of spatial differentiation of allele frequencies. Reduced levels of variability could result from either small present population sizes or the founder effect during colonization.

High mortality during the overwintering period was recorded in British populations of the wingless riverine waterstrider, Gerris najas (Brinkhurst, 1966). In a six-year study, win- 
ter mortality was always greater than $55 \%$, and sometimes exceeded $90 \%$, in each of four populations. Populations of $G$. remigis were much smaller in the spring than in the summer or fall (Zera and Saks, unpubl.), indicating that high winter mortality may also occur in this species. Population bottlenecks resulting from high winter mortality can severely reduce variability (Nei, 1975), and may be an additional factor responsible for the low variability found in populations of $G$. remigis.

Spatially homogeneous allele frequencies among populations of $L$. canaliculatus may be the result of extensive dispersal and gene flow. However, homogeneous allele frequencies do not necessarily imply extensive gene flow since only a small amount of gene flow is needed to swamp out local differentiation due to random drift (Lewontin, 1974). Similar allele frequencies in different populations may also be due to locality-independent balancing selection in the absence of gene flow. Therefore, allozyme data for L. canaliculatus cannot decisively separate the relative contributions of dispersal, selection and drift. However, several additional points should be made. Dispersal is reported to commonly occur in many winged gerrid species (Brinkhurst, 1960; Vepsäläinen, 1971; Callahan, 1974; Landin and Vepsäläinen, 1977). Winged adults of $G$. lacustrus have been found hibernating far from water (Douglas, 1882; Brinkhurst, 1960) and winged forms of the continental European species, G. rufoscutellatus, have been found in Britain (Brinkhurst, 1960). Winged gerrids have been found in small pools on top of three story buildings (Calabrese, 1974) and in the laboratory winged morphs of

L. canaliculatus commonly fly from containers. Hence, it seems unlikely that dispersal is restricted in L. canaliculatus.

The importance of flight dispersal as a factor responsible for the homogeneous allele frequencies in nearly all populations of $L$. canaliculatus may also be inferred by examining allele frequencies in the one population where flight dispersal seems to be severely reduced, the Bass River population. The Bass River population was the only surveyed population of $L$. canaliculatus which was composed almost exclusively of wingless individuals (94\% wingless individuals, Table 1). The almost total absence of winged individuals indicates that gene flow via flight into Bass River must be severely reduced. Both the Est-3 and the Me loci exhibit highly divergent allele frequencies in this population, compared with other populations of $L$. canaliculatus (Table 3). Thus, as in G. remigis, when dispersal by flight is severely reduced, genetic differentiation may result. The generality of this hypothesis is being tested further by investigations of differences among populations of $L$. canaliculatus composed predominantly of wingless morphs.

\section{SUMMARY}

The relationship between degree of winglessness and genetic structure was investigated in two waterstrider species (Gerridae: Hemiptera) with differing degrees of winglessness: the nearly wingless Gerris remigis and the wing-polymorphic Limnoporus canaliculatus. Five of six polymorphic loci in G. remigis exhibited significant spatial variation of allele frequencies. There was fixation or near fixation of different alleles in different populations at three loci. In contrast, five of seven polymorphic loci surveyed in L. canaliculatus exhibited geographically homogeneous allele frequencies. Average heterozygosity in G. remigis ( $H$ $=0.058 \pm 0.026)$ was one-quarter the value of L. canaliculatus $(\mathrm{H}=0.234 \pm 0.072)$ and was one-third to one-quarter the value for "typical" insects or invertebrates.

These data indicate that differing degrees of winglessness have resulted in very different genetic structures in the two species.

\section{Acknowledgments}

Special thanks are extended to my advisor Alari H. Brush and members of my committee, Carl Schaefer and Fred A. Streams, for much encouragement and constructive criticism. Mr. Cecil Smith collected and sent L. canaliculatus from Athens, Georgia. Diane Calabrese pro- 
vided information on collecting localities near Storrs, Connecticut, and provided valuable assistance in the initial stages of this project. Mr. and Mrs. Raymond E. Saks generously provided food and lodging during many of my collecting trips. Lawrence Harshman, David Innes, Richard K. Koehn, Graham Mark and Peggy Saks read earlier drafts of this manuscript. This work was supported by NSF grant DEB 7620967 to Alan H. Brush and USPHS grant GM 21133 to Richard K. Koehn.

\section{Literature Cited}

Anderson, N. 1976. The Limnogonus and Neo-Gerris of the old world with character analysis and reclassification of the Gerrinae (Hemiptera: Gerridae). Entomol. Scandin. Suppl. 7:7-96.

Avise, J. C., \& R. K. Selander. 1972. Evolutionary genetics of cave-dwelling fishes of the genus Astyanax. Evolution 26:1-19.

Ayala, F. J., J. R. Powell, M. L. Tracey, C. A. Mourao, \& S. Perez-Salas. 1972. Enzyme variability in the Drosophila willistoni group. IV. Genic variation in natural populations of Drosophila willistoni. Genetics 70:113-139.

Bobb, M. L. 1951. The life history of Gerris canaliculatus Say in Virginia (Hemiptera: Gerridae). Va. J. Sci. 4:102-108.

Brinkhurst, R. O. 1960. Alary polymorphism in the Gerroidea (Hemiptera-Heteroptera). J. Anim. Ecol. 28:211-230.

- 1966. Population dynamics of the large pondskater Gerris najas Degeer (Hemiptera-Heteroptera). J. Anim. Ecol. 35:13-25.

Calabrese, D. M. 1974. The biology of the species of Gerris Fabricius in Connecticut. M.S. Thesis. University of Connecticut.

1979. Pterygomorphism in 10 Neartic species of Gem 's. Amer. Midl. Natur. 101:61-68.

Callahan, J. R. 1974. Observations on Gerris incognitus and Gerris gillettei (Heteroptera: Gerridae). Proc. Entomol. Soc. Wash. 76:15-21.

Conover, W. 1971. Practical Nonparametric Statistics. Wiley, N.Y.

Douglas, J. W. 1882. Gerris lacustris recorded in hibernation far from water. Entomol. Mon. Mag. 19:20.

Drake, C. J., \& H. M. Harris. 1934. The Gerrinae of the western hemisphere. Ann. Carnegie Mus. 23:179-240.

Laing, C., G. R. Carmody, \& S. B. Peck. 1976. Population genetics and evolutionary biology of the cave beetle Ptomophagus hirtus. Evolution 30:484 498.

Landin, J., \& K. Vepsäläinen. 1977. Spring dispersal flights of pond-skaters Gerris spp. (Heteroptera). Oikos
29:156-160.

Lewontin, R. C. 1974. The Genetic Basis of Evolutionary Change. Columbia University Press, N.Y.

Lewontin, R. C., \& J. Felsenstein. 1965. The robustness of homogeneity tests in $2 \mathrm{x} \mathrm{n}$ tables. Biometrics 21:19-30.

McKechnie, S. W., P. R. Ehrlich, \& R. R. White. 1975. Population genetics of Euphydryas butterflies. I. Genetic variation and the neutrality hypothesis. Genetics 81:571-594.

Nei, M., T. Maruyama, \& R. Chakraborty. 1975. The bottleneck effect and genetic variability in populations. Evolution 29:1-10.

Penn, G. H., \& R. M. Goldsmith. 1950. The life history of the southern water strider, Gerris canaliculatus (Hemiptera, Gerridae). J. Tenn. Acad. Sci. 25:76-81.

Powell, J. R. 1975. Protein variation in natural populations of animals. Evol. Biol. 8:79-119.

Riley, C. F. C. 1920. Migratory responses of water-striders during severe droughts. Bull. Brooklyn Entomol. Soc. 15:1-10.

Saura, A., O. Halkka, \& J. Lokki. 1973. Enzyme gene heterozygosity of Philaenus spumarius (L.) (Homoptera). Genetica 44:459-473.

Selander, R. K. 1976. Genic variation in natural populations, p. 21-45. In F. J. Ayala (ed.), Molecular Evolution. Sinauer Assoc., Inc., Sunderland.

Selander, R. K., M. H. Smith, S. Y. Yang, W. E. Johnson, \& J. B. Gentry. 1971. Bio-chemical polymorphism and systematics in the genus Peromyscus. I. Variation in the old-field mouse (Peromyscus polionotus). Univ. Texas Publ. 7 103:49-91.

Shaw, C., \& R. Prasad. 1970. Starch gel electrophoresis of enzymes - a compilation of recipes. Biochem. Genet. 4:297-320.

Sokal, R. R., \& F. J. Rohlf. 1969. Biometry. W. H. Freeman Co., San Francisco.

Varvio-Aho, S., O. Jarvinen, \& K. Vepsäläinen. 1978. Enzyme gene variation in three species of water-striders (Gerris) (Heteroptera, Gerridae). Ann. Ent. Fenn. 44:87-94.

Varvio-Aho, S., \& P. Pamilo. 1979. Genic differentiation of Gerris lacustris populations. Hereditas 90:237-249.

Vepsäläinen, K. 1971. The role of gradually changing daylength in determination of wing length, alary dimorphism and diapause in a Gerris odontogaster (Zett.) population (Gerridae:Heteroptera) in South Finland. Ann. Acad. Sci. Finn. A, IU Biologica 183:1-25.

- 1978. Wing dimorphism and diapause in Gerris: determination and adaptive significance, p. 218-253. In H. Dingle (ed.), Evolution of Insect Migration and Diapause. Springer-Verlag, N.Y.

Workman, P. L., \& J. D. Niswander. 1970. Population studies on southwestern Indian tribes. II. Local differentiation in the Papago. Amer. J. Hum. Genet. 22:24-29.

Corresponding Editor for Evolution: J. R. Powell 